\title{
The impact of leadership style on ethical decision-making, the moderating role of strategic thinking: a study among Malaysian managers
}

\author{
Vishalni Balasubramaniam ${ }^{1}$, Yashar Salamzadeh ${ }^{1 *}$, Christopher Richardson ${ }^{1}$, and Andrey Plakhin ${ }^{2}$ \\ ${ }^{1}$ Graduate school of business, Universiti Sains Malaysia, 11800, Pulau Pinang, Malaysia \\ ${ }^{2}$ Ural state university of economics, management and entrepreneurship department, Ulitsa 8 Marta, 62/45, Yekaterinburg, \\ Sverdlovsk Oblast, 620144, Russia
}

\begin{abstract}
This study develops and empirically tests a multilevel model of cross-level interactions between leadership style and ethical decision-making at the individual level. The study also examines the moderating role of strategic thinking support in the proposed cross-level relationships. Data were collected from 389 managers of electrical and electronic (E\&E) companies in Penang. These data were evaluated using a partial least square-structural equation demonstrating via SmartPLS. Results confirmed the relationship between leadership style and ethical decision-making. Additionally, strategic thinking was found to perform the moderating role between leadership style and ethical decision-making. This research contributes to the literature on leadership styles and ethical decision-making. In recent times, no such study in (E\&E) manufacturing context has been reported in Malaysia. Also using strategic thinking as a moderator is another novelty of this research.
\end{abstract}

\section{Introduction}

The concept of leadership is one of the most studied organizational phenomena by researchers and is identified as the pivot of the evolution of the organizations [1]. Therefore, the organizations need the right leadership style to make an appropriate decision about their business in order to survive in this competitive environment.

Leadership is the capability to inspire others to perform to accomplish the objectives set [2]. Building the style of leadership is the way of encouraging people, providing path to accomplish the wanted objective [3]. According to Kumar et al. (2019), a leadership style may either inspire or depress workers which, in effect, contribute to higher or lower rates of efficiency [4]. Successful leaders also follow styles that deliver employees with idea and empower them to think creatively [5]. Various forms of leadership exist, including transformational and transactional leadership. Transformational leaders concentrate on the creation of human resources which can transform an organization into creative [6].

Decisions are taken at various stages of the organization. Those who reach a higher level of moral reasoning are more likely to exhibit greater consistency with higher levels of moral action, ethical decision making depends upon personality differences. It is also explained that other factors may also be influential in ethical decision making that include self-concept, life experiences, together with wider personality differences that include emotions. Each person has one's own views, thoughts and understanding.

Strategic thinking is a method of analysis performed by individuals to innovatively reinterpret the roles and behaviors most frequently held in relation to the strategy of the organization. This style of thought is also called out-of-the-box thought. Gross (2015), identified that 'a way to solve a strategic complication that blends logical and convergent tactic with innovative and different thought' also can be defined as strategic thinking [7]. According to Pisapia and Glick-Cuenot (2010), strategic thinking is the opposite of linear thinking or preserving the position quo, and therefore this method of thinking involves the individuals to use reflection, system thinking, and reframing expertise [8].

Being an important contributor to Malaysia's economic, Malaysian E\&E industry still faces significant challenges in maintaining growth with growing competition from Taiwan, Singapore, China and other Asian countries. The E\&E's share of Malaysia's exports has gradually declined from 59 percent in 2010 to 41 percent in 2017.

Previous research results showed there are positive and negative significant occurred among the leaders. However, the research found that there is systematic leniency bias when respondents rated subordinates. According to Graham, Ziegert, and Capitano (2015), inspirational and charismatic transformational leaders have resulted in higher rates of unethical proorganizational behavior (UPB) than transactional leaders in their research [9]. Their findings expand the

* Corresponding author: yashar@usm.my 
interpretation of UPB, include theoretical frameworks to clarify why this activity happens, and add to the philosophy of leadership and work on ethical decisionmaking.

Several leaderships and ethics researchers argue that the cycle of transformational leadership is centered on a different collection of ethical principles relative to transactional leadership. Transformational leadership describes a large amount of change in the formal code of ethics, and transactional leadership describes a considerable increase in diversity preparation when the size of company and values are controlled. Additionally, Kumar et al., (2019), said the transformational leaders has a huge influence than laissez-faire and transactional leaders on decisions, in banking industry [4]. However, there are very little empirical research done about the impact of leadership styles on ethical decision making. Thus, this paper will investigate the impact of leadership style on ethical decision making with moderating role of strategic thinking. The following research objectives have been developed to achieve this research aim. In short, this study aims:

i. To test the impact of transformational leadership style on ethical decision making.

ii. To test the impact of transactional leadership style on ethical decision making.

iii. To test the impact of transformational leadership style moderating role of strategic thinking.

iv. To test the impact of transactional leadership style moderating role of strategic thinking.

\section{Literature Review}

\subsection{Ethical Decision-Making}

The challenge that researchers have is that ethical decision making is not a term that can be simply defined, as it appears to include multiple influences such as individual difference, that include personality and environmental factors, that can affect ethical/ unethical behavior. There appears to be a lack of agreement as to a single agreed definition of ethical judgment within business ethics literature. This is supported by Onyebuchi (2011) who advises that there is no universal consensus, and the definition of ethics is broad. As claimed by researchers in certain cases, ethical decisions are simple enough for people to be able to determine what to do and for business executives to behave appropriately [10]. Ethical decision-making is a problem when exceptions are made and there is confusion regarding ethical responsibilities.

A hermeneutical viewpoint has been added by Keller et al, (2007) to strengthen the previous ethical model, which include egoism, utilitarianism, religion and deontology [11]. The consequential theory is one of the perspectives of normative ethics, which embraces egoism and utilitarianism as two main components of ethical decision making [12,13].

Utilitarianism is one of the moral sources which is rooted in the desire to produce an optimum outcome. Therefore, the greatest value is the output of the ethical decision-making process. A given behavior directly serves the desires of a person as it contributes something to the total amount of satisfaction for him or her or decreases the overall level of discomfort for him or her.

Moreover, in this model Keller et al, (2007) found that the matters that brings only positive for the decisionmaker must take into consideration [11]. This implies that while a decision is conflicting to the needs of others, it is right if it serves the benefit of the decision-maker. Furthermore, Rodgers et al. (2009) illustrated egoism as it is focused on persons behaving in accord per their own interests [14]. This has been also explained that egoism is the wish of maximizing one's own interest.

Vivier (2013) theorized Deontological ethics as an ethic that refers to moral roles, obligations, responsibilities and values, irrespective of the implications of an action [15]. According to Modarres \& Rafiee, (2011) this concept hence concentrates on the action and also the outcome of the respective action [16]. Deontology is the desire to do the absolute right thing regardless about action's outcome and whose interests are affected by doing the right thing [17]. The deontological ethics suggests that the ethical approach is one that includes acts which have an underlying moral meaning. As rules, what can and cannot be achieved occurs.

A different use of the term "moral" is the opposite of the term "amoral." The term "moral" has been defined as there is something within the subject of "right and wrong", whereas "amoral" term means something outside that subject. When subordinates perceive a lack of integrity and ethical intentions in their leadership, they are more likely to engage in unethical behaviors themselves $[18,19]$. A mitigating factor in the increase in unethical behavior is an individual's ethical beliefs. One study found that those individuals who had a strong belief in universal moral rules were less likely to behave unethically [20].

\subsection{Leadership Style}

Leadership is discussed widely in the management literature as a soft skill and individual knowledge $[21,22]$. Leadership also can be defined as the power which can persuade others to perform to accomplish the objectives set [2]. Leadership is the capacity to inspire others to collaborate for common objectives [23]. Leadership is the process of directing and steering a group in one direction. Leadership style is a critically important characteristic of managers. It is described that leadership style is a way used by a leader to influence the behaviors of followers. The framework of transactional and transformational leadership has provided significant support for leadership style research. The methods of transactional and transformational leadership are the most critical and commonly used for leadership studies since 1990. Burns (1978) firstly developed the both leadership style then Avolio and Bass (1991) expanded the styles [24,25]. Transformational leaders satisfy higher needs by engaging the whole person and identify potential in order 
to motivate followers to accomplish a goal [26], whereas leaders who employ the exchange system, in which they motivate followers through rewards, and punishments for something in return, are considered transactional leaders [26]. It is clear that each of leadership styles has their own strengths and weaknesses.

Transformational leaders are constructive, encourage and empower followers to accomplish higher order goals by shaping the values, convictions, behaviors and actions of supporters [6,27]. Transformational leadership style values employees' ideal and values, motivates them to put organization interest on the first place, and drives them to achieve the state of best self [25]. Additionally, transformational leadership discusses the fundamental processes that affect various outcomes. Furthermore, the leaders who following transformational leadership style inspire their subordinates knowledgeably, creatively and deliver a clear idea within their organizations. Transformational leaders also concentrate on the creation of human resources which can assist to transform the organization into a creative organization [28].

Transactional leadership style is a leadership model using various compensation to exchange outcomes needed. Transactional leadership style is a task-oriented and interactive leader manner. Transactional leadership style helps organizations achieve their goals by making job reward and remuneration clear [25]. The transactional leadership style has been categorized through leader-follower conversation. Transactional leadership style involves a sort of a carrot and a stick approach or a combination of a reward and punishment. According to Yahaya and Ebrahim (2016) leaders who employ the exchange system, in which they motivate followers through rewards, and punishments for something in return, are also considered as a transactional leadership style [26]. Transactional leadership supports the logical and money-oriented approach by explaining the purpose of distributing the incentives for objective achievement $[29,30]$.

\subsection{Strategic Thinking}

Baumgartner and Korhonen (2010) added that strategic thinking is contributing to sustainable organizational growth [31]. In addition, Low \& Ang (2012) has defined strategic thinking that an informal process of thinking regulation can help itself or the organization to look forward to a long-term goal [32]. This has been more explained by Gross (2015), "a way to solve a strategic complication that blends logical and convergent tactic with innovative and different thought" [7].

Current researchers stress the importance of three primary cognitive mechanisms, including systems thinking, reframing, and reflection as performance drivers for corporate leaders in coping with situational uncertainty [33]. Furthermore, Pisapia and Glick-Cuenot (2010) explained more about strategic thinking as it is an opposite of linear thinking [8]. Leaders struggle to achieve the goal in complicated situation, because they are depending on linear thinking [33].
Such three mechanisms assist leaders in interpreting the problem over the reframing process; build practical theories to direct behavior over the reflecting process; and using system thinking in a method of holistic [33]. Modern researchers highlight that the whole in system thinking is main then the parts are minor [33]. Reframing is described as a reasoning method to gather and organize the information collection to describe the situational realities. Reflecting is defined as the capacity to interpret information and adapt it according to the specific requirements [33] through practice.

\section{Hypothesis Development}

\subsection{Leadership Style and Ethical Decision- Making}

The purpose of this correlational study was to determine if an impact exists between leadership styles and ethical decision-making as perceived by managers in $\mathrm{E} \& \mathrm{E}$ organizations. Leadership has been one of the most researched and still being perplexing areas of inquiry in business [3]. By valuing the ethic of justice, leaders can contribute to management policies and rules. There are many researchers identified the impact of leadership style on ethical decision making. Eberlin and Tatum (2008) described said that transformational leaders were valued higher on social justice, while transactional leaders were valued high on structural justice [34]. This proved that ethical decision making playing an important role in an organization for better outcomes. Transactional leadership is associated with the computational belief between transformational leadership, which is associated with a lower grade of non-ethical behavior [35].

Burns (1978) proposed that transformational leaders appeal to higher ideals such as justice and equality and that "both leader and follower are raised to higher levels of motivation and morality" [25]. Bass and Bass (1985), however, in his initial iteration of transformational leadership argued that depending upon their motivation, transformational leaders could be moral or immoral [36]. Burns (1978) clearly believed that transformational leadership was moral leadership [25]. In accordance with Burns' declaration, "The effect of transforming leadership is a bond of common stimulation and upliftment". Priestino's (2014) studies examined transformational leadership and ethical action beliefs to assess if there is a relationship [37]. The study initiates a strong link between perceived ethical behavior and transactional and transformational leadership. In short, leadership has been linked to a person's capability, ability, and degree of influence to move people in a direction, to make decisions, and to do things that they would not normally have undertaken. leaders following transformational style use an extensive variety of data sources to make corporate decisions meanwhile the transactional leaders are more likely to limit the details they use in making decisions. Based on previous studies, this research introduced leadership styles as a mediator between crisis traits and decision-making styles [38,39]. 
H1: There is a significant relationship between transformational leadership and ethical decisionmaking.

H2: There is a significant relationship between transactional leadership and ethical decision-making.

\subsection{Leadership Style and Ethical-Decision Making, Moderating Role of Strategic Thinking}

Strategic thinking has been studied in both management and psychological literature, with management literature concentrating on the mechanism of strategic thinking and strategic decision-making, while psychological literature focuses on factors influencing strategic thinking and decision-making. Kaplan et al. (2014) pioneered the idea of a strategy map that "provides a graphic representation of the vital goals of a company" in order to support the strategic thinker's "system thinking" [40]. Strong strategic skills are correlated with strong organizational success. Strategic thinking is concluded as an important for current and future business strategies to lead organizations [41].

The emphasis of the transactional leaders is on established performance objectives, mission commitment, job priorities and task-related skills. This form of leadership is underpinned by a clear interaction between each person concerned on the basis of mutually agreeable promises. O'Regan et al. (2004) quantitatively evaluated the style of leadership, strategy, and performance achievement [42]. They observed that transactional leadership was strongly associated with short-term success and had an internal focus. Love and Roper (2015) indicated that meanwhile the transactional style became associated with management, smaller organizations saw the advantages of transactional style managers because they can track and monitor subordinates' output [43]. Norzailan, et al. (2016) suggested a range of strategic thinking skills that are necessary for successfully participate, reasoning, and to deliver critical judgement [44].

H3: Strategic thinking moderates' relationship between transformational leadership and ethical decision-making.

H4: Strategic thinking moderates' relationship between transactional leadership and ethical decisionmaking.

The literature was used as the basis for the creation of a conceptual structure for this analysis, as shown in Figure 1.

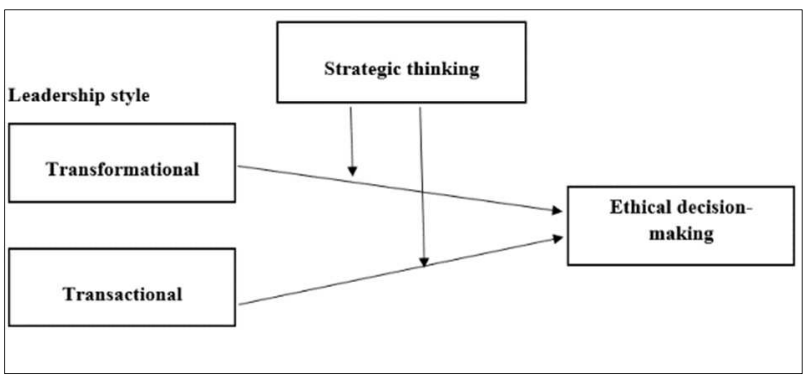

Fig. 1. Conceptual framework

\section{Methods}

\subsection{Research Design}

This study focusses on managers from electrical and electronics (E\&E) companies located in Penang. The mentioned sampling frame was selected because the $E \& E$ industry is the largest single contributor to the manufacturing sector, accounting for $26.1 \%$ of total manufacturing output. Measured by share of value added by state, in 2018 Penang made the highest contribution at $32.5 \%$ of total value added in the E\&E sector. In short, Malaysia's rapid industrialization and high ranking among the world's leading trading nations have contributed largely to this E\&E industry. The sampling frame of this study is gained from the Federation of Malaysia Manufacturers (FMM) directory 2018. Based on the FMM, there are total of 2,787 manufacturing firms in Malaysia and total of 39 E\&E in Penang. Total Employment in E\&E Industry is approximately 100,000. The sample of 389 Penang E\&E managers are selected in this research.

A review of leadership studies shows that almost every research method has been applied to study leadership, which include observation, experiments, surveys, interviews, and content analysis. Similarly, studies of ethical leadership, have applied both quantitative and qualitative methods. In this study, the quantitative methodology was chosen. To accomplish the desired research objectives, an online survey form has been shared to the managers through WhatsApp and emails. 389 managers answered the online questionnaire and there are 55 questions included demographic. Respondents were required to answer all the questions mandatorily.

\subsection{Measurement instruments}

A structured questionnaire has been used in this study. Multi-item scales were used to measure leadership style, ethical decision-making and strategic thinking. A questionnaire was adapted from previous research and updated to suit the framework of this research. The survey questionnaires are divided into four parts Including (1) Transformational leadership with 10 items adapted from Avolio and Bass's (2004) multi factor leadership questionnaire [45], (2) Transactional leadership with 5 items adapted from the same source as previous section, (3) Ethical decision-making adapted from Keller et al. (2007) and Epstein and Spalding (1993) [11,46] and finally (4) Strategic thinking with three sub-dimension as system thinking, reframing and reflecting with total 23 items adapted from Pisapia et al. (2005; 2010) [8,33]. 


\section{Findings}

\subsection{Data Analysis}

Common method variance needs to be examined, when data have been obtained from a single source. The results indicate that 9 of the items explains 63.36 per cent and the first element clarified 36.94 per cent, which is less than 50 per cent. The Partial Least Squares technique by the SmartPLS 3.0 software [47] has been applied to analyse this study model. This software was used to test the measurement model (validity and reliability) and structural model (testing the relationship among variables).

\subsection{Measurement Model}

In this study, the latent variable of ethical decisionmaking was calculated as a second-order, reflective construct where first-order constructs leadership style (transformational leadership and transactional leadership) keep the reflective measurements corresponding to the reflective form. On the basis of literature, higher order is used to limit the number of interactions (and at the same time the number of theories to be tested) in the structural model; and to make the PLS path model more parsimonious and simpler to comprehend.

The validity of convergence and discrimination were used to study the measurement model. The average variance extract (AVE), factor loading, and composite reliability need to be considered when assessing convergent validity. The test shows that all the items loading and AVEs values are higher than 0.5, and CR was above 0.8 (Table 1).

This study used HTMT technique in assessing discriminate validity. As shown below in Table 2, all the values are lower than the required threshold of HTMT 0.90 , this indicates that discriminate validity has been ascertained.

Table 1. Measurement table

\begin{tabular}{|c|c|c|c|c|c|}
\hline & $\begin{array}{l}\text { Ite } \\
\text { ms }\end{array}$ & $\begin{array}{l}\text { Loading } \\
\text { S }\end{array}$ & AVE & CR & Rho_A \\
\hline \multirow{10}{*}{$\begin{array}{l}\text { Transforma } \\
\text { tional } \\
\text { Leadership }\end{array}$} & A1 & 0.948 & 0.972 & 0.994 & 0.997 \\
\hline & A2 & 0.945 & & & \\
\hline & A3 & 0.974 & & & \\
\hline & $\mathrm{A} 4$ & 0.989 & & & \\
\hline & A5 & 0.972 & & & \\
\hline & A6 & 0.956 & & & \\
\hline & A7 & 0.987 & & & \\
\hline & A8 & 0.986 & & & \\
\hline & A9 & 0.950 & & & \\
\hline & $\begin{array}{l}\text { A1 } \\
0\end{array}$ & 0.995 & & & \\
\hline $\begin{array}{l}\text { Transaction } \\
\text { al }\end{array}$ & B1 & 0.901 & 0.855 & 0.983 & 0.994 \\
\hline
\end{tabular}

\begin{tabular}{|c|c|c|c|c|c|}
\hline \multirow[t]{4}{*}{ Leadership } & B2 & 0.895 & & & \\
\hline & B3 & 0.881 & & & \\
\hline & B4 & 0.895 & & & \\
\hline & B5 & 0.896 & & & \\
\hline \multirow{10}{*}{$\begin{array}{l}\text { Ethical } \\
\text { Decision } \\
\text { Making }\end{array}$} & $\mathrm{C} 1$ & 0.983 & \multirow[t]{10}{*}{0.878} & \multirow[t]{10}{*}{0.728} & \multirow[t]{10}{*}{0.999} \\
\hline & $\mathrm{C} 2$ & 0.942 & & & \\
\hline & $\mathrm{C} 3$ & 0.792 & & & \\
\hline & $\mathrm{C} 4$ & 0.979 & & & \\
\hline & $\mathrm{C} 5$ & 0.978 & & & \\
\hline & C6 & 0.905 & & & \\
\hline & C7 & 0.980 & & & \\
\hline & $\mathrm{C} 8$ & 0.919 & & & \\
\hline & C9 & 0.894 & & & \\
\hline & $\begin{array}{l}\mathrm{C} 1 \\
0\end{array}$ & 0.981 & & & \\
\hline Strategic & D1 & 0.524 & \multirow[t]{23}{*}{0.513} & \multirow[t]{23}{*}{0.825} & \multirow[t]{23}{*}{0.878} \\
\hline \multirow[t]{22}{*}{ Thinking } & D2 & 0.580 & & & \\
\hline & D3 & 0.557 & & & \\
\hline & D4 & 0.573 & & & \\
\hline & D5 & 0.646 & & & \\
\hline & D6 & 0.510 & & & \\
\hline & D7 & 0.629 & & & \\
\hline & D8 & 0.596 & & & \\
\hline & D9 & 0.523 & & & \\
\hline & $\begin{array}{l}\text { D1 } \\
0\end{array}$ & 0.561 & & & \\
\hline & E1 & 0.850 & & & \\
\hline & E2 & 0.889 & & & \\
\hline & E3 & 0.831 & & & \\
\hline & E4 & 0.879 & & & \\
\hline & E5 & 0.900 & & & \\
\hline & E6 & 0.880 & & & \\
\hline & E7 & 0.882 & & & \\
\hline & F1 & 0.591 & & & \\
\hline & $\mathrm{F} 2$ & 0.511 & & & \\
\hline & F3 & 0.567 & & & \\
\hline & $\mathrm{F} 4$ & 0.510 & & & \\
\hline & F5 & 0.584 & & & \\
\hline & F6 & 0.562 & & & \\
\hline
\end{tabular}

\subsection{Structural model}

It is advisable to ensure that there is no lateral collinearity issue in the structural model, before evaluating the structural model. This study refers to the Variance Inflation Factor (VIF) to assess multicollinearity issue, since multiple predictors are tested. Based on the result shown in table 3, all the VIF values are lower than 5 .

There were 4 direct hypotheses developed between the constructs, in this study. To examine the significance level, t-statistics for all paths are generated using SmartPLS 3.0 bootstrapping function. Based on the assessment of the path coefficient, four relationships were found to have t-value 3.471 , thus significant at 0.01 level of significance. Specifically, the predictors of transformational leadership $(b=1.393, p<0.01)$, and 
transactional leadership $(\mathrm{b}=1.336, \mathrm{p}<0.01)$, are positively related to leadership style, which explains 65.4 per cent of ethical decision-making. Thus, $\mathrm{H} 1$ and $\mathrm{H} 2$ are supported.

Hypotheses $\mathrm{H} 3$ and $\mathrm{H} 4$ focused on the testing of the moderating effect of strategic thinking between leadership style and ethical decision-making. Therefore, assessment of moderation effect for Structural Equation Model (SEM) with the bootstrapping test was conducted. Based on the earlier examination, it was found that the two hypotheses (H3 and H4) moderated the relationship, and these hypotheses fulfilled the conditions required to establish the moderation relationship proven through their significant indirect effects where t-value 3.471, thus significant at 0.01 level of significance.

Table 2. Discriminant Validity (HTMT)

\begin{tabular}{|c|c|c|c|c|}
\hline & 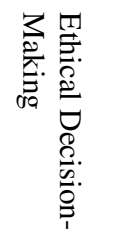 & 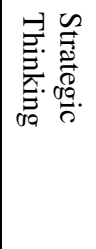 & 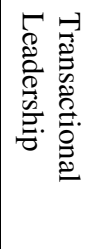 & 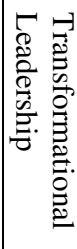 \\
\hline $\begin{array}{l}\text { Ethical Decision- } \\
\text { Making }\end{array}$ & & & & \\
\hline Strategic Thinking & 0.530 & & & \\
\hline
\end{tabular}

\begin{tabular}{|l|l|l|l|l|}
\hline $\begin{array}{l}\text { Transactional } \\
\text { Leadership }\end{array}$ & 0.450 & 0.660 & & \\
\hline $\begin{array}{l}\text { Transformational } \\
\text { Leadership }\end{array}$ & 0.465 & 0.717 & 0.883 & \\
\hline
\end{tabular}

To measure the moderating effect of strategic thinking, an interaction, as an extra latent variable has been added to the model. This interaction describes how the outcome of leadership style on ethical decisionmaking changes when the moderating variable is increased by one standard deviation. Consequently, the positive effect of leadership style on ethical decisionmaking is stronger when strategic thinking is high.

In addition, the effect size $\left(f^{2}\right)$ is evaluated. The Cohen's recommendation is used for computing the size of outcome. The standards of $0.02,0.15$ and 0.35 characterize small, medium, and large outcome correspondingly. In table 3, we observed transformational leadership (0.135) and transactional leadership (0.087) has small effect size in producing $\mathrm{R}^{2}$ for ethical decision-making.

Blindfolding procedure was applied to study the predictive relevance of the model. If $\mathrm{Q}^{2}$ value is larger than 0 , the model has predictive relevance for a certain endogenous construct. The transformational leadership (0.120) and transactional leadership (0.089) are more than 0 , indicating that the model has sufficient predictive relevance. Table 4 shows the indirect hypotheses testing results.

Table 3. Direct Hypotheses testing

\begin{tabular}{|c|c|c|c|c|c|c|c|c|c|c|}
\hline Hypothesis & Relationship & $\begin{array}{c}\text { Std } \\
\text { Beta }\end{array}$ & $\begin{array}{c}\text { Std } \\
\text { error }\end{array}$ & $\begin{array}{c}\mid \mathrm{t}- \\
\mathrm{valu}^{\wedge}\end{array}$ & Decision & $\mathrm{f} 2$ & $\mathrm{q} 2$ & $\begin{array}{c}95 \% \\
\text { CI } \\
\text { LL }\end{array}$ & $\begin{array}{c}\text { 95\% } \\
\text { CI } \\
\text { UL }\end{array}$ & VIF \\
\hline $\mathrm{H} 1$ & $\begin{array}{c}\text { Transformational } \\
\text { Leadership -> } \\
\text { Ethical } \\
\text { Decision- } \\
\text { Making }\end{array}$ & 1.393 & 0.369 & $3.946^{* *}$ & Supported & 0.135 & 0.120 & 0.889 & 2.002 & 4.369 \\
\hline $\mathrm{H} 2$ & $\begin{array}{c}\text { Transactional } \\
\text { Leadership -> } \\
\text { Ethical } \\
\text { Decision- } \\
\text { Making }\end{array}$ & 1.336 & 0.344 & $3.875^{* *}$ & Supported & 0.086 & 0.089 & 0.827 & 1.937 & 4.759 \\
\hline
\end{tabular}

Table 4. Indirect Hypotheses testing

\begin{tabular}{|l|l|l|l|l|l|l|l|}
\hline Hypothesis & Relationship & $\begin{array}{l}\text { Std } \\
\text { Beta }\end{array}$ & Std error & $\mid \mathrm{t}$-value|^ & Decision & $\begin{array}{l}\text { 95\% CI } \\
\text { LL }\end{array}$ & $\begin{array}{l}\text { 95\% CI } \\
\text { UL }\end{array}$ \\
\hline H3 & $\begin{array}{l}\text { TF-ST-EDM -> Ethical Decision- } \\
\text { Making }\end{array}$ & 1.426 & 0.417 & $3.471^{* *}$ & Supported & 0.768 & 2.161 \\
\hline H4 & $\begin{array}{l}\text { TS-ST-EDM -> Ethical Decision- } \\
\text { Making }\end{array}$ & 1.932 & 0.45 & $4.297^{* *}$ & Supported & 1.181 & 2.735 \\
\hline
\end{tabular}

\section{Discussion}

The purpose of this study was to explore the association of transformational and transactional leadership styles with various ethical decision-making among Penang E\&E managers. We hypothesized that transformational leaders significantly use ethical decision-making and we proved where the regression analyses supported the hypotheses. This research explains the managers of Penang E\&E companies are following transformational leadership style in leading their team. As a result, the managers those following transformational leadership style are attentive to the needs of their employees, focuses on helping them to meet their potential, and consider ethical consequences while making a decision. The transformational managers are also being more 
integrity to their employees which accordance with prior works.

The research has showed that the style of transactional leadership has a significant relationship with ethical decision-making as per mentioned in the literature. The positive relationship of transactional leadership style with ethical decision-making is shown a lesser degree than the relationship between transformational leadership style and ethical decisionmaking. Transactional leadership is based on a give and take between leader and follower that includes reward and discipline. The Penang E\&E company managers those applied transactional leadership style in their job responsibility tend to make their own ethical decision even they consider as reasonable and money-oriented attitudes toward leader and employees [30]. The managers make a clear expectation regarding the given task towards to their team and work out agreements with their team.

Moreover, the moderator role of strategic thinking also given a positive impact on both leadership style and ethical decision making. Transformational leaders tend to follow the system thinking and reflecting criteria from strategic thinking variable. The reframing criteria has been highly rated by the managers who following transactional leadership style. This study proven that the moderating role of strategic thinking strongly supporting the managers to make an ethical decision-making. The strong ties between transformational, transactional and strategic thinking indicate that, since strategic thinking is therefore linked to leadership types, leaders should support and develop strategic thinking habits. Strategic thinkers can deal with strategy variations because they think about why, what, how and when in each case, consider capital, and are effective at scheduling to find the right response [48].

To conclude it can be stated that decisions are highly situational, and leaders need to apply their wisdom in making such ethical decisions. The study found that there is slightly difference among the rates of transactional and transformational style of leadership where the managers in Penang E\&E following more transformational leaderships style than transactional. Understanding the relationship between leadership style and ethical decision-making can be important for E\&E manufacturing companies to avoid bias and increase effectiveness.

\subsection{Implications}

The present study outlines various theoretical implications for E\&E managers by identifying leadership styles that foster positive result in ethical decisionmaking. Precisely, outcomes of this study indicate that transformational and transactional leadership style have a positive impact on ethical decision-making. Ethical decision-making is important to managers, which eventually translate into organizational success. As established in the previous research, this research also proven that ethical decision-making helps the transformational managers to avoid unethical behaviour.
Additionally, this research has identified that there is a strong relation between transformational leadership style and leader integrity which has been explained earlier. As an evidence we can evidently see that E\&E managers listen to their team concerns and consider moral and ethical consequences while applying a decision. On the other hand, the managers following transactional leadership style, feel the need to make immediate choices thus limit the details they use in making decisions. Penang E\&E company managers tend to make their own ethical decision even they consider as reasonable and money-oriented attitudes toward leader and employees. As shown in this study the manager with strategic thinking is determined as a significant for ethical decision-making which leads to organization success.

Additionally, the present study also provided practical contribution. By empathetic the impact and differences between both leadership styles on ethical decision-making, managers will get an opportunity to know the accurate leadership style that they are currently following. Furthermore, managers also will realize and understand the importance of ethical decision-making, which can give an impact by their own leadership style. Organizations could give considerable weight for moderating role of strategic thinking in the process of making ethical decisions. This study positively will help the organizations in hiring or positioning the managers into specific team based on their leadership style. This method may ease the management to avoid giving a negative impact or conflict to occur among the team, due to the ethical decision making by the managers.

In conclusion, the rather incidental findings regarding the impact of leadership styles and ethical decisionmaking are fascinating. They lend credence to the concept of leadership and may serve as an additional support to its concurrent validity. Regarding leadership and ethical decision-making more studies are needed. A good idea might be narrowing the study by limiting the population of participants and demographic in the study. It is logical to assume that being aware of one's ethical decision-making style, as well as leadership styles, may help to focus on achieving the organization objectives, develops necessary skills, and deals in a better way with a given situation such as problem solving, motivating, and interacting with others in organizations.

\section{Conclusion}

Though insightful, this study's findings need to be considered in light of certain limitations. The data of this study were only collected from the E\&E sector based in Penang since it is the most important state in terms of Malaysia's E\&E industry according to reports. Given the variations among different sectors and regions, the empirical validity of the current study may not be so solid, and we propose that future scholars test our study with more evidence. The demographic outcome of this current study does not reflect our nation's population pattern where the Malays respondents were represented as the smallest group of respondents. Future studies can 
choose different geographical or industrial which can show the accurate demographical based of ethnicity of our nation to test the main impact.

Furthermore, this study finds strategic thinking moderating role in the relationship between leadership style (transformational and transactional) and ethical decision-making. However, leaders might follow different leaderships styles which can also impact the ethical decision-making. Therefore, a similar study could be developed by future researchers using different leadership styles such as authentic leadership style and servant leadership style in different sectors with different employee's positions. Even the future research can use different moderating role such strategic vision and strategic mindset to find the more stronger moderating role between leadership style and ethical decisionmaking.

In spite of the shortcomings of this article, a number of useful contributions to the discourse on leadership style and ethical decision-making are nevertheless provided. The relevance of these problems needs to be more addressed in future studies.

\section{References}

1. L. Cappelletti, S. Khalla, F. Noguera, A. Scouarnec, and C. V. Fourboul, Manag. Avenir 263 (2010)

2. Z. M. Elqadri, Int. Educ. Stud. 8, 183 (2015)

3. S. A. Z. Kazmi, M. Naarananoja, and J. K. Wartsila, Procedia-Social Behav. Sci. 229, 387 (2016)

4. M. Kumar, S. Pandey, V. Sinha, and A. P. Srivastava, J. Dev. Entrep. 24, 1950025 (2019)

5. D. O. Almutairi, Int. J. Bus. Manag. 11, 231 (2016)

6. J. Giddens, J. Prof. Nurs. 34, 117 (2018)

7. R. Gross, Glob. Bus. Econ. (2015)

8. J. Pisapia and S. Glick-Cuenot, Am. Inst. High. Educ. 3 (1), 179-188, (2010)

9. K. A. Graham, J. C. Ziegert, and J. Capitano, J. Bus. Ethics 126, 423 (2015)

10. V. N. Onyebuchi, Int. J. Bus. Soc. Sci. 2, (2011)

11. A. C. Keller, K. T. Smith, and L. M. Smith, Crit. Perspect. Account. 18, 299 (2007)

12. O. C. Ferrell and L. G. Gresham, J. Mark. 49, 87 (1985)

13. S. M. Goodarzi, Y. Salamzadeh, and A. Salamzadeh, in Compet. Emerg. Mark. (Springer, 2018), pp. 503-539

14. W. Rodgers, A. Guiral, and J. A. Gonzalo, J. Bus. Ethics 86, 347 (2009)

15. E. Vivier, African J. Bus. Ethics 7, (2013)

16. A. Modarres and A. Rafiee, Soc. Responsib. J. (2011)

17. K. D. Martin and J. B. Cullen, J. Bus. Ethics 69, 175 (2006)

18. Y. N. Ng and Y. Salamzadeh, Int. J. Bus. Sci. Appl. Manag. 15, (2020)

19. D. K. Peterson, J. Bus. Ethics 49, 371 (2004)

20. M. Nejati, Y. Salamzadeh, and C. K. Loke, Soc.
Responsib. J. (2019)

21. C. Kimble, J. B. de Vasconcelos, and Á. Rocha, Inf. Syst. Front. 18, 1119 (2016)

22. J. B. de Vasconcelos, C. Kimble, and Á. Rocha, Inf. Syst. Front. 18, 1035 (2016)

23. P. G. Northouse, Leadership: Theory and Practice (Sage Publications, 2021)

24. B. M. Bass and B. J. Avolio, Res. Organ. Chang. Dev. 4, 231 (1990)

25. J. M. Burns, Leadership (New York: Harper \& Row, 1978)

26. R. Yahaya and F. Ebrahim, J. Manag. Dev. (2016)

27. Y. Salamzadeh, M. Kianmanesh, and T. Vahidi, Int. J. Sustain. Strateg. Manag. 7, 186 (2019)

28. M. K. Copeland, J. Leadership, Account. Ethics 13, 79 (2016)

29. F. Bushra, U. Ahmad, and A. Naveed, Int. J. Bus. Soc. Sci. 2, (2011)

30. M. L. Khan, N. Langove, F. A. Shah, and M. U. Javid, Glob. Bus. Manag. Res. 7, (2015)

31. R. J. Baumgartner and J. Korhonen, Strategic Thinking for Sustainable Development (Wiley Online Library, 2010)

32. K. C. P. Low and S.-L. Ang, Educ. Res. 3, 502 (2012)

33. J. Pisapia, D. Reyes-Guerra, and E. CoukosSemmel, Leadersh. Rev. 5, 41 (2005)

34. R. J. Eberlin and B. C. Tatum, Manag. Decis. (2008)

35. L. T. Tuan, Soc. Responsib. J. (2012)

36. B. M. Bass and M. Bass Bernard, Leadership and Performance beyond Expectations (Free press New York, 1985)

37. C. A. Priestino, Leadership Styles and Ethical Behavior: An Examination of Subordinate Perceptions, (Capella University, 2014)

38. Y. Hur, P. T. Van Den Berg, and C. P. M. Wilderom, Leadersh. Q. 22, 591 (2011)

39. S. Geiger, P. Guenzi, N. Panagopoulos, and S. Dimitriadis, Eur. J. Mark. (2009)

40. S. Kaplan, J. Cortina, G. Ruark, K. LaPort, and V. Nicolaides, Leadersh. Q. 25, 563 (2014)

41. E. F. Goldman and A. Casey, J. Leadersh. Organ. Stud. 17, 119 (2010)

42. N. O'Regan, A. Ghobadian, and M. Sims, $J$. Small Bus. Strateg. 15, 45 (2004)

43. J. H. Love and S. Roper, Int. Small Bus. J. 33, 28 (2015)

44. Z. Norzailan, S. M. Yusof, and R. Othman, $J$. Adv. Manag. Sci. 4, (2016)

45. B. J. Avolio and B. M. Bass, Mind Gard. Inc. Menlo Park. CA (2004)

46. M. J. Epstein and A. D. Spalding, The Accountant's Guide to Legal Liability and Ethics (1993)

47. C. Ringle, D. Da Silva, and D. Bido, Bido, D., Da Silva, D., Ringle, C.(2014). Struct. Equ. Model. with Smartpls. Brazilian J. Mark. 13, (2015)

48. O. Szekely, Transitional Justice Arab Spring 94 (2015) 